\title{
List of the original publication venues
}

1. 'IS KLEOS AFQITON a Homeric Formula?' CQ 36 (1986) 1-5.

2. 'Homer's View of the Epic Narrative: some formulaic evidence', CP 82 (1987) 135-38.

3. 'A note on Some Metrical Irregularities in Homer', CP 83 (1988) 206-11.

4. 'Formulaic and Nonformulaic Elements in Homer', CP 84 (1989) 179-97.

5. 'Homer, a Poet of an Individual Style', SCl 16 (1997) 1-8.

6. 'Oral Theory and the Limits of Formulaic Diction', OT 19/2 (2004) 236-52.

7. 'More on KLEOS AFQITON', CQ 57 (2007) 341-50.

8. 'Late Features in the Speeches of the Iliad', in $\emptyset$. Andersen and D.T.T. Haug (eds.). Relative Chronology in Early Greek Epic Poetry. Cambridge (2012) 80-95.

9. 'Oral Formulaic Theory and the Individual Poet', in F. Montanari, A. Rengakos and Ch. Tsagalis (eds.). Homeric Contexts. Neoanalysis and the Interpretation of Oral Poetry. Berlin/Boston (2012) 73-82.

10. 'Equivalent Formulae for Zeus in Their Traditional Context', in A.I. Cooper, J. Rau and M. Weiss (eds.). Multi Nominis Grammaticus: Studies in Classical and Indo-European Linguistics in Honor of Alan J. Nussbaum on the Occasion of his Sixty-fifth Birthday. Ann Arbor/New York (2013) 44-49.

11. 'The First Song of Demodocus', Mnemosyne 40 (1987) 128-32.

12. 'A Creative Oral Poet and the Muse', AJP 111 (1990) 293-303.

13. 'How Could Achilles' Fame Have Been Lost?' SCI 11 (1991/92) 22-37.

14. 'The Sources of Iliad 7', in H.M. Roisman and J. Roisman (eds.). Essays on Homeric Epic. Colby Quarterly 38/2 (2002) 151-61.

15. 'The End of the Heroic Age in Homer, Hesiod and the Cycle', Ordia Prima 3 (2004) 11-24.

16. 'Homer and His Peers: Neoanalysis, Oral Theory, and the Status of Homer', Trends in Classics 3 (2011) 197-208.

17. 'Meta-cyclic Epic and Homeric poetry', in M. Fantuzzi and Ch. Tsagalis (eds.). The Greek Epic Cycle and Its Ancient Reception. A Companion. Cambridge (2015) 126-38.

18. 'The Formation of the Homeric Epics', in F.-H. Mutschler (ed.). Singing the World. The Homeric Epics and the Chinese Book of Songs. Foundational Texts Compared. Newcastle upon Tyne (2018) 15-38.

19. 'Royal Succession in Heroic Greece', CQ 41 (1991) 303-16.

20. 'Odysseus and the Genus “Hero”', G\&R 42 (1995) 1-14.

21. 'Patterns of Human Error in Homer', JHS 115 (1995) 15-28.

22. 'Timē and Aretē in Homer', CQ 48 (1998) 15-28.

23. 'Homer and the Bottomless Well of the Past'. A review article of I. Malkin, The Returns of Odysseus (Berkeley 1998), SCI 21 (2002) 243-50.

24. 'Greece in the Eighth Century BCE and the Renaissance Phenomenon', in Sh. Shaked (ed.). Genesis and Regeneration. Essays on Conceptions of Origins. Jerusalem (2005) 62-76.

25. 'Ajax's Entry in the Hesiodic Catalogue of Women', CQ 38 (1988) 31-41.

26. 'The Cypria, the Iliad, and the Problem of Multiformity in Oral and Written Tradition', CP 95 (2000) 1-11.

27. 'Homer as a Foundation Text', in M. Finkelberg and G.G. Stroumsa (eds.). Homer, the Bible and Beyond: Literary and Religious Canons in the Ancient World. Leiden/Boston (2003) 75-96. 
28. 'She Turns About in the Same Spot and Watches for Orion: ancient criticism and exegesis of Od. $5.274=I l .18 .488$ ', GRBS 44 (2004) 231-44.

29. 'Regional Texts and the Circulation of Books: the case of Homer', GRBS 46 (2006) 231-48.

30. 'Canonising and Decanonising Homer: Reception of the Homeric Poems in Antiquity and Modernity', in M. Niehoff (ed.). Homer and the Bible in the Eyes of Ancient Interpreters. Leiden/Boston (2012) 15-28.

31. 'Homer at the Panathenaia: some possible scenarios', in Ch. Tsagalis and A. Markantonatos (eds.). The Winnowing Oar - New Perspectives in Homeric Studies. Studies in Honor of Antonios Rengakos. Berlin/Boston (2017) 29-40. 